\title{
Is Self Talk of Athletes One of the Determinants of Their Continuous Sportive Confidence Level?
}

\author{
Nazmi Bayköse ${ }^{1}$, Filiz Şahin ${ }^{2}$, Ahmet Şahin ${ }^{2}$, Mehmet Emre Eryücel $^{1}$ \\ ${ }^{1}$ Akdeniz University Faculty of Sport Sciences, Turkey \\ ${ }^{2}$ Mehmet Akif Ersoy University, Department of Physical Education and Sports. Turkey \\ Correspondence: Nazmi Bayköse, Faculty of Sport Sciences, Akdeniz University, Turkey.
}

Received: October 18, 2018

Accepted: November 7, $2018 \quad$ Online Published: January 28, 2019

doi:10.11114/jets.v7i2.3999

URL: https://doi.org/10.11114/jets.v7i2.3999

\begin{abstract}
The present study aims to determine whether level of self talk behaviors of athletes is one of the determinants of their continuous confidence levels. Whereas totally 358 athletes $\left(X_{\text {age }}=23.77 \pm 3.87\right)$ were voluntarily participated into this study, 180 of them were female $\left(X_{\text {age }}=22.76 \pm 3.050\right)$ and 236 of them were male $\left(X_{\text {age }}=24.56 \pm 4.263\right)$. Experiences of various branches of team sport and personal sports (soccer, basketball, volleyball, tennis, athletics, biking and etc.) in sport activities were determined as $98.25 \pm 24.70$. Whereas descriptive statistical methods were employed in analysis and assessment of collected data; t-test and multiple step regression analysis was utilized in independent samples. Aforesaid analyses were conducted through the SPSS package software and significance level was considered as $\mathrm{P}<0.05$. According to the study findings, a significant positive linear correlation was determined between self talk behaviors of athletes and their continuous sportive confidence. Furthermore, it was observed that self talk behavior of athletes was one of the significant determinants of their continuous sportive confidence levels. Finally, it is possible to conclude that continuous sportive confidences, one of the important psychological factors in performances of athletes, were correlated with their self talk behavior of athletes and that it was one of the significant determinants of continuous sportive confidence levels.
\end{abstract}

Keywords: sport, self talk, sportive confidence

\section{Introduction}

One of the basic pillars comprising sport concept is undoubtedly performance. Within the boundaries of contemporary sport science founded on performance, researchers have spent great effort to reveal determinants of performance and to develop factors believed to have positive contribution into performance these influent factors for long years.

In addition to physiologic performance dynamics, contribution of psychological performance dynamics has long been acknowledged. In this regard, self-confidence is seen as one of the psychological factors which determine performance sport activities (Vealey, Hayashi, Garner-Holman, Giacobbi, 1998). Vealey et al. (1998), who introduced self-confidence into the sport concept into the literature and further developed it, have oriented on establishment of foundation of theoretical resources of self-confidence in sport and to develop valid and reliable measurement tool to measure this foundation (Hays et al., 2007). Researchers indicate sportive self-confidence as one of the psychological factors which plays significant roles in high level of performance in addition to physical characteristics in sport environments (Vealey, Hayashi, Garner-Holman, \& Giacobbi, 1998).

It is another fact that psychological factors, essentially important for all contemporary athlete, who strive for success, are required to be determined and comprehended by scientists (Hatzigeorgiadis, Zourbanos, Mpoumpaki \& Theodorakis, 2009; Şar and Işıklar, 2012). According to the relevant literature, there are two different concepts about sport confidence come to prominence. Although these concepts are studied under "Self-confidence" and "Sport confidence", indeed they represent the same psychological phenomenon (Vealey, 1986). Mentioned psychological phenomenon will be taken within the present study as "Sport confidence". Individual sportive self-confidence relate with dimensions such as capability to learn and apply physical skills (imagining, transition to state of flow), ability to use psychological skills (making decision, adjusting to conditions), ability to use perceptional skills and being satisfied with the physical appropriateness level (Weinberger, 2003). It is addressed that origins of sport self-confidence sense are among the positive determinants of sport performance. Furthermore, origins of sport self-confidence are positively correlated with other performance (Swain and Jones, 1992; Duda, 1992). 
In study of Şar and Işıklar (2012) examining focus of control, subjective well-being and optimism as estimators of sport confidence, it is revealed that significant positive correlation between sport confidence level and internal focus of control belief, subjective well-being; and internal focus of control belief, subjective well-being, optimism levels are significant estimators of sport confidence level. Based on this information, it is possible to conclude that sport confidence is related with positive psychological factors. It is considered that theoretical research on sport confidence plays important role as well. Self-talk could have determinant role for sport confidence when motivational and cognitive function processes are considered as positive components because researchers claim that self-talk is related in various ways with (either internally or externally) attitudes and behaviors of individuals (Brinthaupt et al., 2009). Reichl et al. (2013) exhibited the relationship between positive self-talk and regulation of attitude and behaviors of persons in their study. Besides attitudes and behaviors, there are literature findings on their impact on determining affection statuses (Bayköse, 2014).

Hatzigeorgiadis, Zourbanos, Mpoumpaki \& Theodorakis (2009) examined the foundation of the relationship between self-talk and performance and reported that motivational self-talk was positive influence on self-confidence level. In the present empirical study, functional role of motivational self-talk on increasing self-confidence level was emphasized. In this theoretical context, our research plays essential role to assess other available findings in the literature. Along all these findings, the researcher aimed to test whether self-talk level of athletes was one of the determinants of their sport confidence levels through this research design. To that end, following questions were tried to be answered in the present study:

1. What is the estimation power of self-talk levels of participant athletes on their sport confidence levels?

2. Whether sport confidence levels of participant athletes differ with respect to their self-talk levels?

3. Whether sport confidence levels of participant athletes with various sport experience differ with respect to their self-talk level?

\section{Materials and Methods}

In this section, research model, research group, measurement tools and statistical methods utilized in this research were exhibited.

\subsection{Research Design}

In this study, survey method (Büyüköztürk, Çakmak, Akgün, Karadeniz and Demirel, 2008; Karasar, 2009) and relational screening model were utilized (Relational Survey Method) (Büyüköztürk et al., 2008; Karasar, 2009; Büyüköztürk, 2014). According to Fraenkel and Wallen (2006), the purpose of relational researches is to investigate the relationships among two or more variables without interfering them. In the meantime, existence and degree of the relationships among dependent and independent variables were tried to be revealed based on the model (Crano and Brewer, 2002). Karasar (2009) describes purpose of relational screening models as determining existence and degree of relationships among two or more variables. On the other hand, screening model is the approach which tries to describe a past or present status as it is. Research subject, which could either be an event, a person or a subject, is tried to be defined within their unique conditions and as is (Karasar, 2009). In the present study, relational research, one of the quantitative research methods, was employed and this constitutes an example of a research conducted based on screening model.

\subsection{Participants}

The present research was consisted of 180 female $\left(X_{\text {age }}=22.76 \pm 3.05\right)$ and 236 male $\left(X_{\text {age }}=24.56 \pm 4.26\right)$ totally 358 athletes $\left(\mathrm{X}_{\mathrm{age}}=23.77 \pm 3.87\right)$ on voluntary basis. Average sport experience of respondent athletes oriented on team-based or individual sport branches (soccer, basketball, volleyball, tennis, athletics, bicycle and etc.) was determined as $98.25 \pm 24.70$ months.

\subsection{Measuring Instruments}

\subsubsection{Self-talk Questionnaire (STQ)}

Self-talk Questionnaire (STQ) (Appendix 1) was developed by Zervas, Stavrou and Psychountaki (2007) to expose individual differences in terms of motivational and cognitive processes concerning self-talk in determined dimensions (Zervas et al., 2007). It was adapted into Turkish by Engür (2011). The scale is comprised of 11 items each of which provide 5 different answer options for respondents :(Never (1); Occasionally (2); Sometimes (3); Mostly (4); and Always (5) and it includes 2 sub-scales. These sub-scales are Motivational Function and Cognitive Function. As Cronbach's alpha value represents internal consistency coefficient, in the study of Engür (2011), it was estimated for "motivational function" and "cognitive function" as 0.93 and 0.87 respectively. In general, reliability coefficient of the scale was estimated as 0.95 (Engür 2011). 


\subsubsection{Trait Sport Confidence Questionnaire (TSCQ)}

The State Sport Confidence (SSGÖ) comprised of 13 items was developed by Vealey (1986) for sport related purposes. State Sport Confidence has single-factor structure. The SSGÖ was adapted into Turkish by Engür and Atatar (2006). After item analysis and confidence analysis on the data set obtained at the end of the SSGÖ sampling process; then Cronbach's Alpha internal consistency reliability coefficient was estimated as 0.94 . additionally, Öner and La Compte's "Continuous Anxiety" scale was applied to sampling in order to test validity of criterion; but, no sufficient level of correlation was determined between this scale and the SSGÖ. This finding suggests that Turkish version of the SSGÖ Scale is psychometrically acceptable; however, it was revealed that further studies are necessary (Engür and Atatar, 2006).

\subsubsection{Personal Information Form}

In order to collect personal information of respondent athletes, personal information form prepared by the researcher was utilized. In the Personal Information From, respondents were asked questions regarding their ages, gender, sport experiences and their current sport branches.

\subsubsection{Data Analysis}

Whereas descriptive statistical methods were employed in interpretation of data, t-test and Multi Stepwise Regression Analysis methods were utilized for independent samples. The SPSS package software was utilized for analyses of collected data; and significance was determined as $\mathrm{P}<0.05$.

\section{Results}

Table 1. Regression Analysis Result Regarding Role of Elite Athletes' Self-Talk Levels in Determining State Sport Confidence Levels

\begin{tabular}{llll}
\hline & $\beta$ & $\mathrm{T}$ & $\mathrm{P}$ \\
\hline Motivational Self Talk & 0,407 & 8,769 & 0,000 \\
\hline Cognitive Self Talk & 0,301 & 6,494 & 0,000 \\
\hline
\end{tabular}

$\mathrm{R}=0,630 ; \mathrm{R} 2=0,397 ;$ Adjusted $\mathrm{R}^{2}=0.394 ; \mathrm{F}_{(2,417)}=137,030 ; \mathrm{p}=0.000$

According to the Multi Stepwise Regression analysis results, a significant relationship was determined between State Sport Confidence levels and elite athletes motivational self-talk levels and cognitive self-talk levels ( $\mathrm{R}=0.63$; $\mathrm{F}=137.030 ; \mathrm{p}<0.05)$. Athletes' motivational self-talk scores and cognitive self-talk scores were able to explain $40 \%$ of the total variance related with their State Sport Confidence levels $\left(R^{2}=0.40 ; p<0.05\right)$.

Table 2. Pearson Correlation Table Indicating the Relationship between State Sport Confidence Levels and Cognitive Self-Talk and Motivational Self-Talk

\begin{tabular}{l|l|l|l|l|l}
\hline & Mean & Std. Deviation & 1 & 2 & 3 \\
\hline 1. Motivational Self Talk & 28,60 & 3,64 & $\mathrm{r}=1$ & & \\
\hline 2. Cognitive Self Talk & 15,70 & 2,15 & $\mathrm{r}=0,572^{* *}$ & $\mathrm{r}=1$ & \\
\hline 3. Sportive Confidence & 101,02 & 10,31 & $\mathrm{r}=0,579^{* *}$ & $\mathrm{r}=0,534^{* *}$ & $\mathrm{r}=1$ \\
\hline
\end{tabular}

According to Table 2, positive and significant relationship was determined between state sport confidence ( $\mathrm{r}=.579$, $\mathrm{p}=.000)$ and motivational function and cognitive function $(\mathrm{r}=.572, \mathrm{p}=.000)$. Additionally, positive and significant relationship was determined between state sport confidence $(\mathrm{r}=.534, \mathrm{p}=.000)$ and cognitive function.

Table 3. t-test Table Results Regarding Effect of Elite Athletes' Self-Talk Levels on the State Sport Confidence Levels

\begin{tabular}{l|l|l|l|l|l|l}
\hline & Gender & $\mathrm{N}$ & Mean & Std. Deviation & $\mathrm{p}$ \\
\hline \multirow{2}{*}{ Motivational Self Talk } & Men & 23628,4661 & 3,42626 & \multirow{2}{*}{, 916} &, 360 \\
\cline { 2 - 6 } & Women & 18028,8000 & 3,86995 & & \\
\hline Cognitive Self Talk & Men & 23615,8814 & 2,06354 & \multirow{2}{*}{1,852} & \multirow{2}{*}{, 065} \\
\cline { 2 - 6 } Sportive Confidence & Women & 18015,4889 & 2,19824 & & \\
\cline { 2 - 6 } & Men & $236100,77129,72246$ & \multirow{2}{*}{, 464} & \\
\cline { 2 - 5 } & Women & 180101,2556 & 11,15213 & & \\
\hline
\end{tabular}

According to results of t-test analysis conducted on independent samples, of the self-talk level dimensions of elite 
athletes, motivational function sub-dimension, did not present statistically significant difference in terms of gender variable $(\mathrm{t}=-0.916 ; \mathrm{p}>0.05)$.

According to results of t-test analysis conducted on independent samples, of the self-talk level dimensions of elite athletes, cognitive function sub-dimension, did not present statistically significant difference in terms of gender variable $(\mathrm{t}=1.852 ; \mathrm{p}>0.05)$.

According to results of t-test analysis conducted on independent samples, elite athletes' State Sport Confidence Level did not present statistically significant difference in terms of gender variable $(t=-0.464 ; p>0.05)$.

Table 4. Anova Test Table Results Regarding the Relationship between State Sport Confidence Level and Their Self-Talk Levels in Terms of Athletes' Sport Experience

\begin{tabular}{l|l|l|l|l|l|l|l}
\hline \multicolumn{2}{l}{} & Sum of Squares & Df & Mean Square & F & p & \\
\hline \multirow{2}{*}{ Motivational Self Talk } & Between Groups & 62,836 & 3 & 20,945 & 1,592 & 191 & \\
\cline { 2 - 9 } & Within Groups & 5473,964 & 416 & 13,159 & & & \\
\cline { 2 - 9 } Cognitive Self Talk & Total & 5536,800 & 419 & & & & \\
\hline \multirow{2}{*}{ Sportive Confidence } & Between Groups & 37,306 & 3 & 12,435 & 2,735 &, 043 & $1-4$ \\
\cline { 2 - 9 } & Within Groups & 1891,685 & 416 & 4,547 & & & \\
\cline { 2 - 9 } & Total & 1928,990 & 419 & & & & \\
\cline { 2 - 9 } & Wetween Groups & 769,677 & 3 & 256,559 & 2,437 &, 064 & \\
\hline
\end{tabular}

According to analysis results, no statistically significant difference was observed on motivational function sub-dimension, one of the self-talk level dimensions of elite athletes, in terms of sport experience variable $(\mathrm{F}=-1.592 ; \mathrm{p}>$ $0.05)$.

According to analysis results, statistically significant difference was observed on cognitive function sub-dimension, one of the self-talk level dimensions of elite athletes, in terms of sport experience variable $(F=-2.735 ; \mathrm{p}<0.05)$.

According to analysis results, no statistically significant difference was observed among athletes' State Sport Confidence levels in terms of sport experience variable $(F=2.437 ; p>0.05)$.

\section{Discussion}

According to the results of the multiple stepwise regression analysis conducted regarding role of athletes' self-talk levels on determining their State Sport Confidence level, a significant relationship was determined between athletes' State Sport Confidence Levels and their motivational and cognitive self-talk levels. Athletes' motivational self-talk scores and cognitive self-talk scores were able to explain $40 \%$ of the total variance observed in their State Sport Confidence Levels. In this regard, it was considered that both cognitive self-talk and motivational self-talk could be determinants of athletes' state sport self-confidence in this model which was theoretically tried. Based on the relevant literature on this theoretically positive relationship;

When it is considered that cognitive and motivational self-talk are positive psychological factors, findings reported by Şar and Işıklar (2012) support the results of the present research. Similarly, the fact that self-talk has supportive characteristic for positive psychological factors beside the determinants of sport confidence level (Baykose, 2014) conforms to our study results. In terms of relational researches oriented on the relationship between State Sport Confidence Level and Cognitive Self-Talk and Motivational Self-Talk, it is possible to conclude that there is positive linear relationship between motivational and cognitive functions of self-talk; and that there is positive linear relationship between state sport confidence and both functions of self-talk. As a result of the analyses conducted, it was determined that these relationships were statistically significant. According to the relevant literature, Hatzigeorgiadis et al. (2009) revealed in their study oriented on the relationship among self-talk, self-confidence and anxiety, that whereas self-talk was positively effective on self-confidence, a reverse relationship existed between self-talk and cognitive anxiety. In this regard, study results of Hatzigeorgiadis et al. (2009) conform to findings of the present study.

Based on the results of the studies investigating the relationship between athletes' self-talk levels and their state sport confidence levels in terms of gender variable, a statistically significant difference was observed with motivational function sub-dimension of athletes' self-talk level levels. On the other hand, no statistically significant relationship was determined with cognitive function sub-dimension of athletes' self-talk levels in terms of gender variable. According to the relevant literature in the context of this finding, study reported by Nergiz et al. (2015) was notable. In the study of Nergiz et al. (2015), conducted on athletes performing modern and folk dances, a statistically significant difference was determined between female and male athletes. On the basis of findings reported by Nergiz et al. (2015), statistically significant difference was reported with female athletes in both cognitive and motivational function sub-dimensions. 
This research results are contradictory with findings of our research. Engür (2011) also reported contrasting results with our research findings. As it was reported by Engür (2011), in terms of gender variable, there is no statistically significant difference. Another research finding that is necessary to be taken into consideration was reported by Hardy et al. (2005). As a result of study of Hardy et al. (2005), no any statistically significant difference was observed in terms of gender variable. It is possible claim that this results support our research findings. According to the results reported by Bayköse (2014), no statistically significant difference existed in terms of gender variable. In this sense, it could be concluded that it display parallelism with our findings and support them.

With respect to athletes' State Sport Confidence levels, no any statistically significant difference was observed in terms of gender variable. When the relevant literature was reviewed concerning these results, research results reported by Ekinci et al. (2014) are not conforming to our findings. In another study in which state sport confidence was investigated in terms of gender variable, Woodman \& Hardy (2003) examined relative effect of cognitive anxiety and self-confidence on performance; and they emphasized self-confidence was more effective among male athletes compared with female athletes. However, in the light of these findings, researchers did not consider basic differences of self-confidence levels.

Based on the results of investigation into the relationship between athletes' self-talk levels and their state sport confidence levels in terms of their sport experience, no any statistically significant difference was observed with motivational function sub-dimension of athletes' self-talk level. However, cognitive function sub-dimension of athletes' self-talk level, statistically significant difference was observed in terms of athletes' sport experience variable. According to results of the comprehensive studies conducted by Hardy et al. (2005), it was reported that self-talk did not exhibit statistically significant difference in terms of athletes' experience variable. In this regard, it is possible to state that our research findings are partly supported; but there are some points not supported as well. According to the research results reported by Bayköse (2014), no statistically significant difference was reported in terms of sport experiences of athletes. Thus, research findings reported by Bayköse (2014) were in contradiction with the present study. In another research conducted by Gammage et al. (2001), it was reported that no statistically significant difference found with self-talk in terms of athletes' sport experience. Gammage et al. (2001) indicated that there is no any relationship between experience in sport and self-talk.

In addition, according to the analysis results, no any statistically significant difference was observed between athletes' state sport confidence levels in terms of their experience level in sport. In the relevant literature, Kolb (1999) reported that one of the important determinants of self-confidence was experience. From this point of view, findings are conflicting with our research results. In another research, Voight et al. (2000) reported in their study conducted on female athletes that increasing experience was one of the determinants of sportive self-confidence. In this sense, it was observed that Voight et al.'s (2000) results are contradictory to the findings of the present study.

In the light of these findings, finally, it could be concluded that State Sport confidence levels of athletes, a significant psychological factor in their performances, are related with their self-talk level and one of the important determinants of their state sport confidence levels. According to our research results, it is possible state that both two sub-dimensions of self-talk are positively related with sport confidence level. Within the framework of the relevant literature findings, it is considered that existence of studies reported in the literature, which supports the findings of this study, could guide researchers in the future to investigate into the relationships between self-talk and psychological factors influent on performance at the first place or directly on performance through empirically designated studies.

\section{References}

Bayköse, N. (2014). Sporcularda Kendinle Konuşma ve İmgeleme Düzeyinin Optimal Performans Duygu Durumunu Belirleyici Rolü. Selçuk Üniversitesi. Sağlık bilimleri Enstitüsü. Beden Eğitimi ve Spor Anabilim Dalı. (Yayımlanmamış) Yüksek Lisans Tezi. Konya.

Brinthaupt, T. M., Hein, M. B., \& Kramer, T. E. (2009). The Self-Talk Scale: Development, factor analysis, and validation. Journal of Personality Assessment, 91, 82-92.

Büyüköztürk, Ş. (2014). Sosyal Bilimler İçin Veri Analizi El Kitabı: İstatistik, Araştırma Deseni SPSS Uygulamaları ve Yorum (Genişletilmiş 20. Baskı), Ankara: Pegem Akademi.

Büyüköztürk, Ş., Çakmak, E. K., Akgün, Ö. E., Karadeniz, Ş., \& Demirel, F. (2008). Bilimsel araştırma yöntemleri (2. Bask1). Ankara: Pegem.

Crano, W. D., \& Brewer, M. B. (2002). Principles and methods of social research. New Jersey, Lawrence Erlbaum Associates Publishers.

Ekinci, N. E., Özdilek, Ç., Deryahanoğlu, G., \& Üstün, Ü. D. (2014). Spor Yapan Lise Öğrencilerinin Öz Güven Düzeylerinin İncelenmesi. Sportif Bakış: Spor ve Eğitim Bilimleri Dergisi, 1(1), 36-42. 
Engür, M. (2011). Performans Başarısızlığı Değerlendirme Envanteri ve Kendinle Konuşma Anketinin Türk Sporcu Popülasyonu'na Uyarlanması ve Uygulanması. Ege Üniversitesi, Sağlık Bilimleri Enstitüsü. Sporda Psikososyal Alanlar Anabilim Dalı. Doktora Tezi, İzmir.

Engür, M. (2011). Performans Başarısızlı̆̆ Değerlendirme Envanteri ve Kendinle Konuşma Anketinin Türk Sporcu Popülasyonu'na Uyarlanması ve Uygulanması. Ege Üniversitesi, Sağlık Bilimleri Enstitüsü. Sporda Psikososyal Alanlar Anabilim Dalı. Doktora Tezi, İzmir.

Engür, M., \& Atatar, S. (2005). Durumluluk ve sürekli sportif güven envanterinin Türkçe’ye Uyarlanması. Performans, 11(3), 7-12. Ege Üniversitesi. İzmir.

Frankel, J. R., \& Wallen, N. E. (2006). How to design and evaluate research in education. New York: McGraw Hill Companies, Inc.

Gammage, K. L., Hardy, J., \& Hall, C. R. (2001). A Description Of Self-Talk İn Exercise. Psychology Of Sport And Exercise, 2, 233-247.

Hardy, J., Hall, C. R., \& Hardy, L. (2005) Quantifying Athlete Self-Talk, Journal Of Sports Sciences, 23(9), 905 - 917.

Hatzigeorgiadis, A., Zourbanos, N., Mpoumpaki, S., \& Theodorakis, Y. (2009). Mechanisms underlying the self-talkperformance relationship: The effects of motivational self-talk on self-confidence and anxiety. Psychology of Sport and exercise, 10(1), 186-192.

Hatzigeorgiadis, A., Zourbanos, N., Mpoumpaki, S., \& Theodorakis, Y. (2009). Mechanisms underlying the self-talkperformance relationship: The effects of motivational self-talk on self-confidence and anxiety. Psychology of Sport and exercise, 10(1), 186-192.

Karasar, N. (2008). Bilimsel araútÕrma yöntemleri. Ankara: Nobel Yayın Dağıtım.

Karasar, N. (2009). Bilimsel Araştırma Yöntemi. Ankara: Nobel Yayınevi.

Kolb, J. A. (1999). The effect of gender role, attitude toward leadership, and self-confidence on leader emergence: Implications for leadership development. Human Resource Development Quarterly, 10(4), 305.

Negiz, S., Bayköse, N., \& Yıldız, M. (2015). Self Talk: The Self-Talk Status Among Modern and Folk Dances Niğde University Journal of Physical Education And Sport Sciences, 9, Special Issue.

Reichl, C., Schneider, J. F., \& Spinath, F. M. (2013). Relation of self-talk frequency to loneliness, need to belong, and health in German adults. Personality and Individual Differences, 54, 241-245.

Şar, A. H., \& Işiklar, A. (2012). Examınatıon Of Locus Of Control, Subjectıve Well-Beıng And Optımısm As The Predictors Of Sport Confidence. Journal of Physical Education \& Sports Science, 6(1).

Theodorakis, Y., Hatzigeorgiadis, A., \& Chroni, S. (2008). Self-talk: It works, but how? Development and preliminary validation of the functions of self-talk questionnaire. Measurement in Physical education and exercise Science, 12(1), 10-30.

Vealey, R. S. (1986). Conceptualization of Sport-Confidence and Competitive Orientation: Preliminary Investigation and Instrument Development. Journal of Sport Psychology, 8, 221-246.

Vealey, R. S., Hayashi, S. W., Garner-Holman, M., \& Giacobbi, P. (1998). Sources of sport-confidence: conceptualization and instrument development. Journal of Sport \& Exercise Psychology, 20(1), 54-80.

Voight, M., Callaghan, J., \& Ryska, T. (2000). Relationship between goal orientation, self-confidence and multidimensional trait anxiety among Mexican-American female youth athletes. Journal of Sport Behavior, 23(3), 271.

Woodman, T., \& Hardy, L. (2003). The relative impact of cognitive anxiety and self-confidence upon sport performance: A meta-analysis. Journal of sports sciences, 21(6), 443-457.

Zervas, Y., Stavrou N., \& Psychountaki M. (2007). Development and Validation of the Self-Talk Questionnaire (S-TQ) for Sports. Journal of Applied Sport Psychology, 19, 142-159.

\section{Copyrights}

Copyright for this article is retained by the author(s), with first publication rights granted to the journal.

This is an open-access article distributed under the terms and conditions of the Creative Commons Attribution license which permits unrestricted use, distribution, and reproduction in any medium, provided the original work is properly cited. 